\title{
Zostera geojeensis, a New Species of Seagrass from Korea
}

\author{
Hyunchur Shin ${ }^{1 *}$, Kang-Hyun $\mathrm{Cho}^{2}$ and Yoon Sik $\mathrm{Oh}^{3}$ \\ ${ }^{1}$ Division of Biological Sciences, Soonchunhyang University, Asan 336-745, \\ ${ }^{2}$ Department of Biology, Inha University, Inchon 402-751 and \\ ${ }^{3}$ Division of Life Sciences, Gyeongsang National University, Chinju 660-701, Korea
}

\begin{abstract}
Zostera geojeensis, a new species from Geojedo Island located on the south coast of Korea, is described and compared with other related species of Zostera. It is very similar to Z. caespitosa Miki in having congested internodes of rhizomes but differs distinctly from that by having obtuse or cuspidate and transparent leaf margins at apices.
\end{abstract}

Key Words: new species, seagrass, Zostera geojeensis

\section{INTRODUCTION}

The genus Zostera L. (Zosteraceae), one of the seagrass genera, consists of 11 species, and are widely distributed in the northern and the southern temperate waters (Hartog 1970). The genus Zostera is divided into two subgenera, Zostera and Zosterella, based on the closed or open sheath in leaf bases and the presence or absence of retinaculum in spadix. The subgenus Zostera which has the closed sheath and no retinaculum, consists of four species, which are distinguished by the number of leaf vein, shape of leaf apex, length of internodes in rhizomes, and striation pattern of seed coat (Hartog 1970). Five species of Zostera, four of subgenus Zostera, and one of subgenus Zosterella, are known to Korea (Shin and Choi 1998); however, additional field surveys have led to recognize the plants described as a new taxon.

\section{SPECIES DESCRIPTION}

Zostera geojeensis Shin, Cho et Oh, sp. nov. Type: Daedaepo port, Nambu-myon, Geojeshi, Gyeongnam, Korea, 9 June 1997, Shin et al. 97054 (Holotype: AJOU, Isotypes: AJOU, SNU). Fig. 2, Plate 1.

Zostera caespitosa Miki affinis, sed folis apice obtusus cum acumine vel obtusus, ligula longioribus, nervi 5 differt.

*Corresponding author (shinhy@sch.ac.kr)

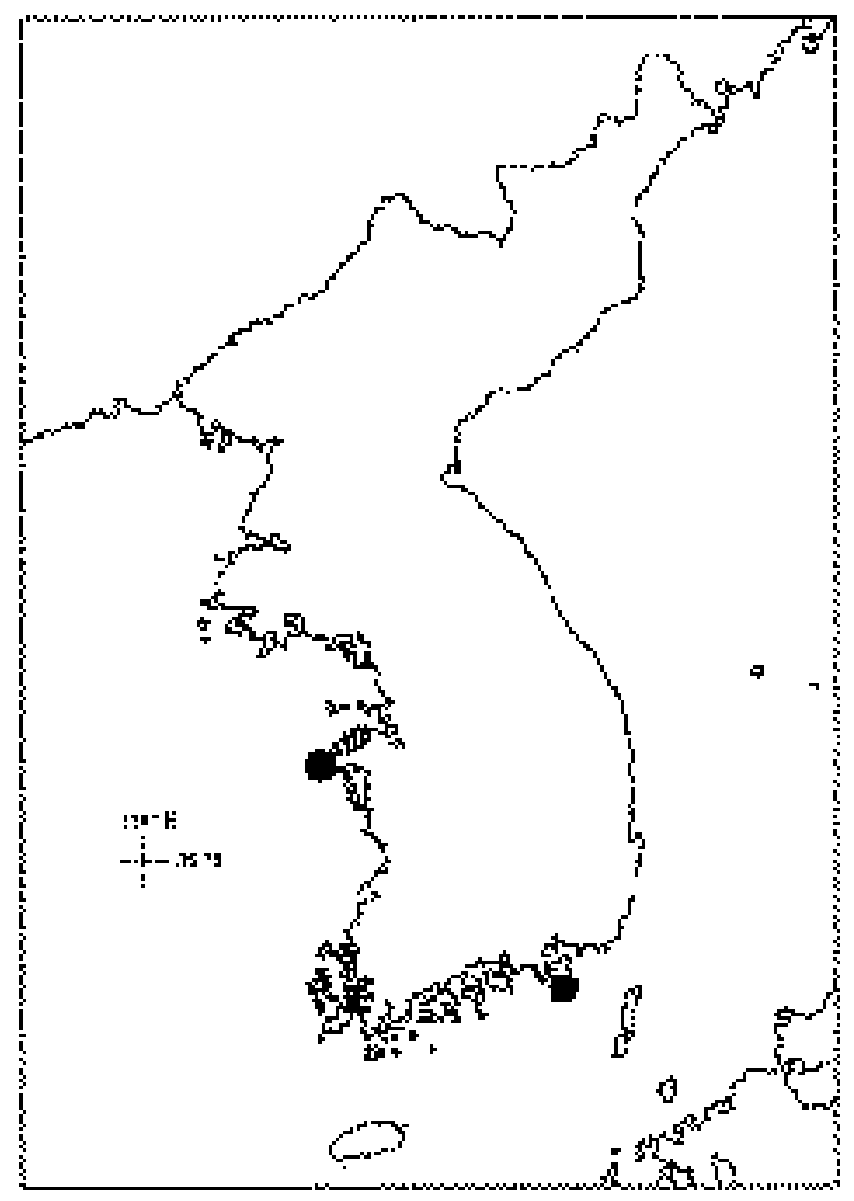

Fig. 1. Distribution of Zostera geojeensis sp. nov.

Rhizomes caespitose, numerous elongated roots and shoot at each node, enclosed by leaf remains; internodes extremely short. Leaves up to $100 \mathrm{~cm}$ long, 4-6 mm 


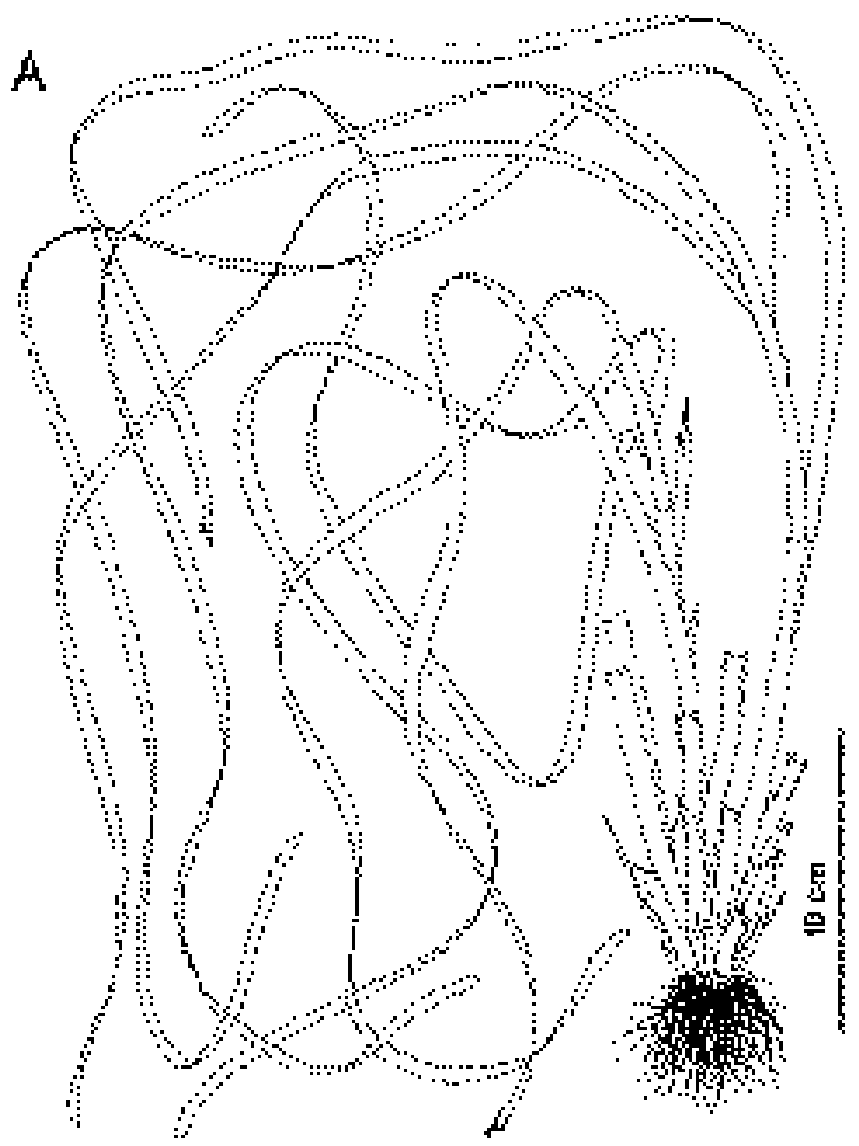

$\mathrm{B}$

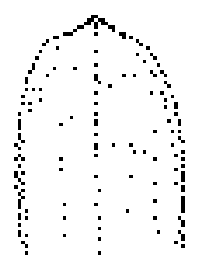

⿷匚⿳丨コ丨コ

t)

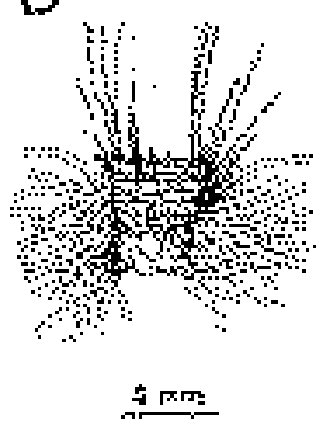

$\mathrm{C}$

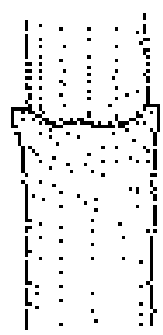

5 배

E

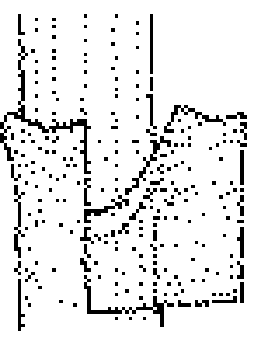

†ाग

Fig. 2. Morphology of Zostera geojeensis sp. nov.

A; habit, B; leaf apex with transparent appendage, C; closed leaf sheath, D; rhizomes, E; mouth of leaf sheath split open to show ligule.

broad, number of veins mostly 5 , intervals between midvein and side vein $0.9-1.2 \mathrm{~mm}$, united in arches or irregularly in apical area; apices obtuse or cuspidate with more or less transparent appendages at margin; leaf sheaths up to $20 \mathrm{~cm}$ long, sclerenchymatous, persistent, becoming irregularly torn with age; auricles 1-2 mm long; ligules 0.4-0.8 mm long. Reproductive organs not observed.

Habitat: Soft bottom with sands or muddy sands at 3$5 \mathrm{~m}$ deep in semiclosed bay.

Paratype: Mongsanpo beach, Chungnam, Korea, 2 September 2000, Shin 20006 (AJOU).

Korean name: 좀마디거머리말 (Jom-madi-geomeorimal)

The plants of Zostera geojeensis were firstly collected without reproductive organs at Dadaepo port located on the south coast of Korea (Fig. 1). The plants grew separately on the soft bottom with muddy sands at 3-5 m deep of the semiclosed bay which were made by break- water built-up. The habit of the plants with caespitose manner in the field differs distinctly from that of the other Zostera species with clear rhizomatous.

The original habitat had been reclaimed at the time after our collection. Other remnant plants were not found around the area when we surveyed again to collect the plants with reproductive organs. The individuals were also collected without reproductive organs at Mongsanpo beach located on the west coast of Korea, geographically far from the original sites (Fig. 1). They grew on shallower soft bottom mixed with sands and mud at the coastal embayment.

Among the species of subgenus Zostera with leaves coated by closed sheaths, Z. geojeensis is distinguished by very shortened internodes in rhizomes, obtuse to cuspidate leaf apices, and more or less transparent leaf margins at apices (Fig. 2). The new species resembles Z. caespitosa vegetatively, especially by its congested internodes, however, the leaf apex of Z. caespitosa is obocordate or deeply emarginate (Miki 1932; Shin and Choi 1998) 


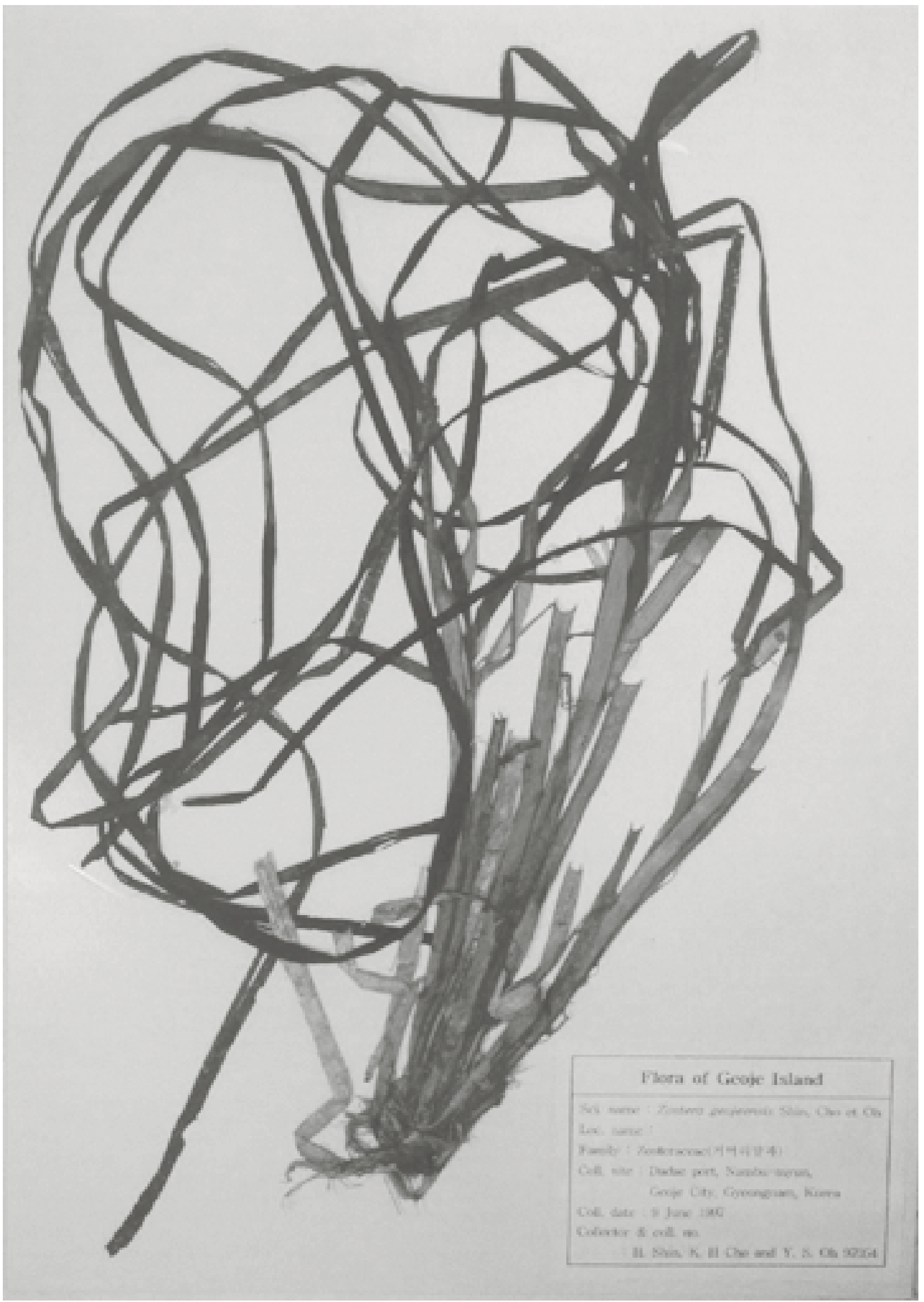


and the leaf breadth are far narrower. The leaf apex of $Z$. geojeensis species is very similar to that of $Z$. marina, however, the internodes of the latter are very long $(1-3 \mathrm{~cm}$ long; $c f$. Shin and Choi 1998) compared to those of the former. Although the reproductive organs were not observed yet, the plants of Zostera, especially those of subgenus Zostera, were easily identified with only the vegetative organs (Miki 1932; Hartog 1970; Shin and Choi 1998), and this suffices for the new species.

\section{ACKNOWLEDGEMENT}

This study was supported by a grant from Soonchunhyang University, Korea (Grant no. 20000118) to the first author.

\section{REFERENCES}

Hartog C. den. 1970. The sea-grasses of the World. Verh. KonNed. Akad. Wetensch. Afd. Natuurk., Tweede Sect. 59: 1275.

Miki S. 1932. On sea-grasses new to Japan. Bot. Mag. Tokyo 46: 774-788.

Shin H. and Choi H.-K. 1998. Taxonomy and distribution of Zostera (Zosteraceae) in eastern Asia, with special reference to Korea. Aquat. Bot. 60: 49-66.

Accepted 24 May 2002 